\title{
JIHAD ONLINE DALAM PERSPEKTIF PENDIDIKAN PESANTREN
}

\author{
Rustam Ibrahim ${ }^{1}$, Moh. Ashif Fuadi ${ }^{1}$ \\ ${ }^{1}$ Universitas Islam Negeri Raden Mas Said Surakarta \\ *Corresponding email: rustamibrahimalfatih@gmail.com
}

Naskah diterima: 4 Juli 2021| Disetujui: 2 Agustus2021 | Diterbitkan: 3 Agustus 2021

\begin{abstract}
The government from 2010 to 2018 has removed at least 814,594 radical content containing hate speech, hoakses, and fighting between communities. In addition, the existence of $19.4 \%$ of Civil Servants (PNS) who do not agree with Pancasila as the basis of the state is a manifestation of the erosion of state ideology by its citizens. In response to this, KH. Said Aqil Siroj ordered all NU youths to carry out online jihad. Online jihad is necessary to counter the many hoakses, slander, and hate speech, and to be able to preserve Aswaja's creed, and of course maintain the integrity of the Unitary State of the Republic of Indonesia. The online jihad application in the perspective of pesantren is carried out by conveying correct arguments Iqomatul Hujjaj (diagnosis), polite rhetoric Dakwah Bil Hikmah Wal Mauidzotil Hasanah (prognosis), and voicing Islam Rahmatan lil Alamin (motivation). Online jihad is a medium to uphold the religion of Islam and a means to gain the pleasure of Allah SWT.
\end{abstract}

Keywords: Jihad, Online Media, Pesantren Education

\begin{abstract}
Abstrak: Media sosial banyak dibanjiri oleh konten radikal yang cukup meresahkan masyarakat. Pemerintah sejak 2010 hingga tahun 2018 telah menghapus setidaknya 814.594 konten radikal yang berisi tentang ujaran kebencian, hoaks, dan adu domba antar masyarakat. Tidak hanya itu, Adanya 19.4\% Pegawai Negeri Sipil (PNS) yang tidak setuju terhadap Pancasila sebagai dasar negara adalah wujud dari lunturnya ideologi negara oleh warganya. Menyikapi hal tersebut, KH. Said Aqil Siroj memerintahkan kepada segenap generasi muda NU untuk melakukan jihad online. Jihad online amat penting untuk mengcounter banyaknya hoaks, fitnah, dan ujaran kebencian. Tujuannya adalah agar mampu melestarikan aqidah aswaja, dan menjaga keutuhan NKRI. Hasil penelitian ini menunjukkan bahwa pengertian jihad dalam istilah syariat dapat dimaknai sebagai perjuangan (bukan hanya peperangan) untuk menegakkan kebenaran dalam menjunjung tinggi agama Islam, termasuk jihad online. Aplikasi jihad online dalam perspektif pesantren dilakukan dengan menyampaikan argumentasi yang benar (iqomatul hujjaj)/(diagnosis), retorika yang santun (Dakwah Bil Hikmah Wal Mauidzotil Hasanah)/(prognosis), dan menyuarakan Islam yang rahmatan lil alamin (motivasional), Tujuan dari jihad online adalah media untuk menegakkan agama Islam dan sarana untuk mendapat Ridha Allah SWT.
\end{abstract}

Kata kunci: Jihad, Media Online, Pendidikan Pesantren 


\section{PENDAHULUAN}

Era digital telah merubah proses transfer ilmu pengetahuan dari konvensional tatap muka ke dunia maya. Apalagi di era pandemi saat ini yang usianya telah mencapai lebih dari satu tahun. Jika sebelumnya proses pembelajaran berlangsung melalui tatap muka antara guru dan murid di sekolah, melalui guru agama di tempat ibadah, melalui lingkungan keluarga sebagai media utama dalam sosialisasi, di era medsos ini beralih secara digital melalui online seperti Zoom, Google Meet, Instagram, Youtube, WhatsApp, Twitter, Facebook, dan media online lain seperti Detik.com, Tribun.com, NU Online, Islamsantun, Tempo.co, dan Alif.id. Pembelajaran berlangsung dengan mudah menggunakan smartphone yang menyediakan layanan android (Sefriyono, 2020).

Masyarakat digital di Indonesia selalu mengalami perkembangan dari tahun ke tahun. Pada tahun 2015, masyarakat pengguna media online sebanyak 93,4 juta dari total 270 juta penduduk Indonesia. Pada tahun 2020 sekitar 64\% pengguna media online dari total penduduk Indonesia dengan total pengakses kira-kira sebesar 174 juta orang. Angka tersebut menjadikan Indonesia sebagai negara dengan masyarakat pengguna media internet terbesar di dunia (Ramadhan, 2020). Dengan semakin meningkatnya pengguna internet, ini menjadi ladang yang efektif bagi pesantren untuk melakukan jihad online dalam menyebarkan faham yang moderat dan Islam rahmatan lil'alamiin.

Di era medsos saat ini, arus informasi begitu mudah didapatkan melalui media sosial. Dengan banyaknya arus informasi yang mudah didapatkan, terjadi banyak perubahan dalam kehidupan bermasyarakat. Termasuk dalam media berjihad. Jihad mengalami perubahan dari yang semula berjalan secara konvensional berubah dalam bentuk media online/digital. Namun yang perlu diwaspadai adalah dalam perkembangannya media sosial banyak dibanjiri konten radikal yang tentunya cukup meresahkan masyarakat. Pemerintah sejak 2010 hingga tahun 2018 telah menghapus setidaknya 814.594 konten radikal yang berisi tentang ujaran kebencian, hoaks, dan adu domba antar masyarakat (Pramesti, 2015). Tidak hanya itu, Adanya 19.4\% Pegawai Negeri Sipil (PNS) yang tidak setuju terhadap Pancasila sebagai dasar negara adalah wujud dari lunturnya ideologi negara oleh warganya (Perdana, 2018).

Gerakan kelompok radikal dalam menyemai benih-benih radikalisme bukanlah isapan jempol belaka, gerakan ini memakai berbagai media online dalam menyebarkan paham radikalisme. Gagasan jihad online dalam rangka membendung radikalisme di media sosial tentu membutuhkan perencanaan, strategi, dan metode terbaik agar dapat diterima dan dipahami oleh masyarakat umum. Dengan menyuarakan jihad online, tentu terjadi pertarungan wacana dan narasi antara gerakan radikalisme agama dan Islam moderat di dunia maya. Oleh karena itu, jihad online perlu dipersiapkan 
dengan sebaik-baiknya, tujuannya agar dapat dipahami dan diterima oleh masyarakat luas, tentunya agar NKRI tetap terjaga dengan sebaik-baiknya (Saidurrahman, 2019).

Pesantren, sebagai lembaga Pendidikan Islam tertua di Indonesia, yang ikut berpartisipasi dalam perjuangan menegakkan Negara Kesatuan Republik Indonesia (NKRI) dan Pancasila, merasa terganggu dengan banyaknya konten radikal yang membanjiri media sosial. KH. Said Aqil Siroj dalam pernyataannya mengungkapkan bahwa pentingnya jihad online untuk mengcounter hoaks, fitnah, adu domba dan ujaran kebencian. Jihad online perlu digalakkan bagi generasi muda agar siap memasuki era globalisasi, era medsos dan era online yang amat mendesak, tujuannya adalah agar mampu melestarikan aqidah aswaja, dan menjaga keutuhan NKRI. Oleh karena itu, pesantren perlu ikut menandingi konten radikal yang ada di media online dengan konten yang moderat dan berpaham inklusif, yakni pemahaman Islam ala Ahlissunnah wal jama'ah.

Dengan mensosialisasikan jihad online bagi generasi muda, terutama generasi pesantren, maka penting bagi para santri untuk mengetahui bagaimana konsep jihad online dalam perspektif pendidikan pesantren, serta bagaimana aplikasi jihad online dalam perspektif pendidikan pesantren.

Jihad online merupakan jihad yang efektif. Dalam perspektif Pendidikan pesantren, jihad yang efektif adalah ketika seseorang mampu menyampaikan kebenaran sesuai dengan situasi dan kondisi masyarakatnya. Hal ini bertujuan agar kebenaran yang disampaikan berjalan efektif dan lancar. Jihad online merupakan salah satu media yang didukung oleh pesantren agar seseorang yang berjihad dapat menyampaikan kebenaran dan menegakkan agama Allah secara efektif dan efisien, sehingga masyarakat tidak mendapatkan gangguan dan paksaan atas ajarannya (Zuhaili, 2001). Bentuk jihad dapat diekspresikan dalam berbagai macam media sosial dan digital yang sesuai dengan kebudayaan masyarakat, baik dengan Website, Twitter, Youtube, Facebook, Instagram, maupun dengan media internet lainnya. Jihad online merupakan sebuah media agar dakwah berjalan efektif, sehingga pembingkaian media dapat berubah-ubah dengan menyesuaikan kondisi masyarakat. Dari pernyataan di atas, dapat dipahami bahwa di era media sosial ini, jihad online merupakan media yang efektif untuk menegakkan syiar agama karena sesuai dengan kebudayaan dan kondisi masyarakat saat ini.

\section{METODE}

Penelitian ini menggunakan metode library research, yakni sebuah penelitian kepustakaan (Hadi, 1989). Riset kepustakaan adalah riset terhadap ajaran atau gagasan yang berkaitan dengan masyarakat, seperti sifat, karakter, pemikiran dan idenya, serta gagasan yang dapat membentuk karakter masyarakat. Penelitian ini termasuk kategori penelitian pustaka (Nadzir, 1996). Metode ini untuk mendapatkan data tentang konsep jihad online dalam perspektif pesantren dengan pendekatan 
deskriptif. Penelitian ini juga dapat disebut dengan studi naskah. Penelitian dengan membuat rekonstruksi teks secara obyektif dan sistematis dengan cara menyusun, menilai, mengumpulkan bukti-bukti, memverifikasi serta mensintesiskan bukti-bukti untuk membuat kesimpulan yang valid (Suryabrata, 1995).

Studi naskah memiliki dua sumber data, pertama data primer dan yang kedua data sekunder. Data primer adalah data asli atau data langsung dari orang/sumber pertama terkait problem yang diteliti. Data tersebut dinamakan data asli (Nawawi, 1995). Data primer yang dimaksud adalah pendidikan pesantren. Sedangkan data sekunder adalah data yang didapatkan dari sumber penunjang, sehingga tidak asli atau tidak langsung, karena didapatkan dari orang atau sumber kedua dan selanjutnya (Nawawi, 1995). Sumber data sekunder digunakan untuk data penunjang atau perbandingan untuk mengidentifikasi konsep dan aplikasi jihad online dalam perspektif pesantren. Teknik analisis data dalam penelitian ini menggunakan teknik analisis deskriptif, yaitu menjelaskan kondisi yang ada, pendapat yang berlangsung, sebab akibat yang terjadi, dan kondisi yang tengah berkembang (Faisal dan Warseso, 1982). Metode penelitian ini digunakan untuk menginterpretasikan konsep dan aplikasi jihad online dalam perspektif pendidikan pesantren.

\section{HASIL DAN PEMBAHASAN}

\section{Pengertian Jihad Online dalam Perspektif Pendidikan Pesantren}

Secara bahasa, jihad bermakna mengerahkan segenap daya dan kemampuan atau bersungguhsungguh dalam melaksanakan perbuatan (Abu Bakr, 1976). Sedangkan jihad secara terminologis memiliki banyak bentuk, bukan hanya bermakna peperangan. Menurut Wahbah Zuhaili (1985), pemahaman jihad yang paling sesuai syariat agama adalah "mencurahkan tenaga dan daya untuk menegakkan agama Allah baik dengan raga, harta, maupun dengan lisan. Hal ini sesuai dengan definisi jihad yang disampaikan oleh Syekh Muhammad Said Ramadlan Al-Buwaithi:

$$
\text { أما معنى الجهاد: فهو بذل الجهد في سبيل إعلاء كلمة الله و إقامة المجتمع الإسلامي }
$$

Makna jihad adalah mengerahkan segala kemampuan untuk menegakkan agama Allah dan dan membentuk masyarakat yang Islami (Al Bhuti, 1991).

Makna jihad di atas bersifat umum dan bukan hanya dengan perang. Jihad juga mengandung makna menyampaikan, mengajarkan dan mendakwahkan agama Islam di masyarakat, demi terciptanya masyarakat yang Islami sesuai dengan ajaran Islam. KH. Bahauddin Nursalim menjelaskan bahwa makna jihad adalah berjuang untuk menegakkan agama Allah SWT dan bukan perang. Kata jihad berasal dari kata jahada yajhadu jihadan, atau kesusahan dan berjuang. Artinya, memikirkan agama Allah itu jihad, siapapun yang berjuang dan bersusah payah dalam 
menegakkan agama Allah disebut jihad (Bahauddin, 2021). Dalam konteks jihad online, orang yang membela agama Allah, meluruskan pemahaman yang keliru, mengantisipasi terhadap gerakan radikalisme, ujaran kebencian, hoaks dan berbagai ajaran yang mengganggu stabilitas negara termasuk jihad.

Konteks jihad untuk menyebarkan ajaran Islam di era kecanggihan teknologi informasi saat ini dapat dilakukan dengan berbagai media, termasuk media sosial. Hal tersebut berdasarkan hadis nabi. Suatu ketika nabi ditanya tentang syair, beliau menjawab bahwa syair dapat digunakan sebagai media untuk berjihad. Sebagaimana hadis shahih yang diriwayatkan Ibnu Hibban (1993) dalam kitab shahihnya:

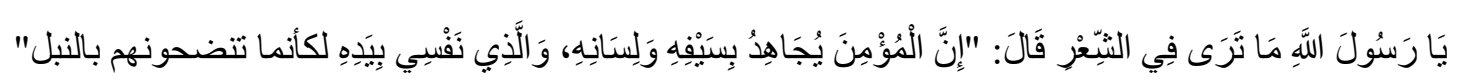

Rasulullah SAW ditanya, bagaimana pendapat Nabi tentang syair? Beliau menjawab: Seorang mukmin berjihad menggunakan senjata dan lisannya, dengan syairmu seakan engkau melempari musuhmu dengan panah (HR. Ibnu Hibban)

Hadis di atas menunjukkan bahwa jihad menyebarkan ajaran Islam dapat dilakukan dengan beragam media, baik media verbal seperti ceramah mengaji atau dengan tulisan. Di era teknologi saat ini berbagai berita dapat menyebar dengan cepat. Banyak informasi tentang agama yang keliru, adanya gerakan radikal yang mengganggu terhadap stabilitas negara, hoaks yang bertebaran, ujaran kebencian, adu domba, gerakan melawan pemerintah, serta kejanggalan dalam memahami agama tersebar di ruang publik, baik melalui media cetak, media sosial, atau visualisasi video di internet. Peran jihad bagi pesantren adalah menjawab, meluruskan, dan menegakkan agama Islam yang yang rahmatan lil alamin dengan memanfaatkan teknologi media yang mutakhir. Jihad seperti ini merupakan fardhu kifayah yang harus dilakukan oleh mereka yang memiliki keilmuan yang mendalam. Termasuk fardhu kifayah apabila menegakkan argumentasi keagamaan dan mengurai kerancuan dalam memahami agama (Himasal, 2019).

Jihad disesuaikan dengan situasi dan kondisi yang mengitarinya. Dengan memandang kondisi saat ini, jihad online merupakan jihad yang paling efektif untuk menumbuhkan kesadaran umat di tengah masyarakat. Jihad online dapat dilakukan dengan menggunakan media sosial seperti Facebook, YouTube, Twitter, Instagram, dan aplikasi online lainnya untuk membentengi akidah Islam ala ahlissunnah wal jamaah dan Negara Kesatuan Republik Indonesia dari serangan kelompok radikalis. Jihad online dalam perspektif pendidikan pesantren dapat dimaknai sebagai perjuangan dengan menggunakan media sosial untuk menegakan kebenaran dalam menjunjung tinggi agama Islam. Jadi perjuangan di media sosial yang dilandasi dengan tujuan untuk menegakan kebenaran agama, dalam perspektif pesantren dinamakan jihad online. 


\section{Aplikasi Jihad Online dalam Perspektif Pendidikan Pesantren}

Aplikasi jihad online dalam perspektif pendidikan pesantren ini menggunakan teori framing. Terdapat tiga fungsi dalam framing peristiwa di media online (Sefriyono, 2020). Pertama, bagaimana media mendiagnosis seberapa pentingnya sebuah berita/ajaran/gagasan jika diberitakan, bagaimana dampak negatif dari ajaran tersebut jika tidak diberitakan. Terkait jihad online dalam perspektif pendidikan pesantren, penulis menelusuri literatur pesantren yang memberikan dasar dalam diagnosis ajaran yang penting untuk diberitakan, dalam pesantren ditemukan ajaran untuk menyampaikan kebenaran (Iqomatul Hujjaj), Kedua, adalah prognosis, yaitu pembingkaian media yang lebih menekankan pada konten yang berisi strategi dalam menyelesaikan kesalahan dan persoalan, dalam pesantren disebut dengan retorika santun (da'wah bil hikmah wal mauidzoh hasanah). Ketiga, bagaimana sebuah berita menjadi menarik hati konsumen media online sebagai sebuah motivasi (Sefriyono, 2020), dalam pesantren biasa disebut dengan ajaran Islam yang penuh kasih sayang (rahmatan lil 'alamin).

Dari tiga fungsi framing di atas, penulis melakukan elaborasi terhadap jihad online dalam perspektif pendidikan pesantren. Dalam fungsi diagnosis, jihad online dalam perspektif pesantren menjadi penting ditulis dalam rangka menandingi beberapa konten yang radikal. Jika konten radikal dan sesat tidak ditandingi dengan konten yang moderat dan lurus, tentu stabilitas negara dan kenyamanan warga negara terganggu. Dalam fungsi prognosis, jihad online dalam perspektif pesantren menjadi strategi yang tangguh dalam rangka menyuarakan retorika santun (da'wah bil hikmah wal mau'idzoh hasanah). Dalam fungsi motivasional, jihad online perspektif pesantren merupakan media utama dalam menyuarakan Islam rahmatan lil 'alamiin, moderat, dan berlandaskan ahlus sunnah wal jama'ah yang berciri khas toleran, moderat, berimbang, dan adil. Selain itu, sudah menjadi kewajiban untuk selalu menyuarakan empat pilar negara, yaitu Pancasila, Bhineka Tunggal Ika, NKRI harga mati, dan UUD 1945.

\section{Diagnosis: Meluruskan Gagasan yang Salah (Iqomatul Hujaj wa Daf'u Syubhat)}

Salah satu fungsi pembingkaian gagasan atau berita di media online adalah diagnosis, artinya adalah membingkai gagasan dengan pertimbangan pentingnya gagasan untuk dimuat serta pertimbangan negatifnya jika tidak dimuat (Sefriyono, 2020). Dalam konteksnya jihad online menjadi penting ketika bertujuan untuk menegakkan kebenaran dan syiar Islam. Sebagaimana tujuan jihad adalah menciptakan masyarakat Islami yang menjalankan syariat dan ajaran Islam (Himasal, 2019). Ketika banyak radikalisme dan berbagai kesalahan yang merugikan agama, tentu bagi pesantren yang pada hakikatnya mencetak ahli agama, berkewajiban untuk turun gunung dalam media online, tujuan utamanya adalah berjihad untuk meluruskan akidah yang sesat, perbuatan yang 
menyimpang, mengantisipasi berkembangnya hoaks, ujaran kebencian, dan adu domba. Sebagaimana sabda nabi:

$$
\text { إذا ظهرت البدع في أمتي وشتم أصحابي فليظهر العالم علمه فإن لم يفعل ذلك فعليه لعنة الله }
$$

Ketika penyimpangan agama muncul di umatku, dan para sahabatku dicaci maki, hendaknya seorang Alim menampakan ilmunya. Jika tidak, ia dilaknat oleh Allah subhanahu wa ta'ala (HR. Dailami)

Imam Muhyiddin An-Nawawi juga menjelaskan bahwa hukumnya wajib kifayah untuk meluruskan akidah sesat, apalagi mengatasnamakan agama. Sebagaimana pernyataan beliau:

$$
\text { ومن فرض الكفاية القيام بإقامة الحجج وحل المشكلات في الدين }
$$

Termasuk fardlu kifayah adalah menjelaskan argumentasi keagamaan dan mengurai kejanggalan dalam memahami agama (Al Nawawi, 2005).

Hal ini sesuai dengan fungsi framing, bahwa diagnosis merupakan sebuah telaah yang fokus terhadap gagasan yang keliru. Dalam pendidikan pesantren, terdapat beberapa kesalahan konten dan gagasan di media sosial yang penting dan mendesak untuk diluruskan.

\section{Jihad terhadap Kesalahan Niat dan Tujuan}

Terjadinya bom bunuh diri di depan gereja Katedral Makasar merupakan sebuah peristiwa yang memilukan bagi Indonesia. Pelaku meninggalkan surat wasiat yang isinya cukup memprihatinkan. Dalam suratnya dituliskan saya tempuh jalanku sebagai mana jalan Nabi/Rasul Allah untuk selamatkan ki dan bisa ki kembali berkumpul di surga. Bersadarkan isi surat tersebut dapat dipahami bahwa tujuan dari pelaku bom bunuh diri adalah menempuh jalan nabi dan Allah SWT. Jika dilihat dari tujuannya, jelas baik dan menggambarkan sebagai orang yang sholih. Namun jika dilihat dari perbuatan kriminalnya, tentu merupakan sebuah kedunguan (Nailul Huda, 2018). Menurut Imam AlGhazali, perbuatan pelaku bom bunuh diri merupakan sebuah kebodohan. Walaupun niatnya baik, namun perbuatannya jelas melanggar syariat agama dan aturan negara. Perbuatan yang dihukumi maksiat, tidak akan berubah statusnya dengan niat baik. Sebagaimana perbuatan pelaku bom bunuh diri, niatnya ingin mencari ridho Allah SWT, namun perbuatannya dapat mengancam nyawa orang lain. Menurut Imam Ghazali orang yang demikian dianggap bodoh, niat dan tujuannya tidak dapat menghapus dan mengeluarkan statusnya dari pelaku criminal/maksiat (Al Ghazali, 1998). Sedangkan aksi bom bunuh diri di negara yang berdaulat jelas merupakan sebuah kesalahan yang tidak dapat dibenarkan. Setidaknya ada empat kesalahan yang dapat ditelusuri dari pendidikan pesantren, yaitu:

1. Bunuh diri adalah larangan agama dan termasuk dosa besar.

2. Aksi bom bunuh diri melukai dan merenggut nyawa muslim 
3. Menyebabkan kerusakan property dan harta orang lain

4. Menyebabkan ketakutan dan trauma di tengah masyarakat serta menimbulkan instabilitas negara (Himasal, 2019).

Gambar di bawah ini merupakan salah satu contoh jihad di media online.

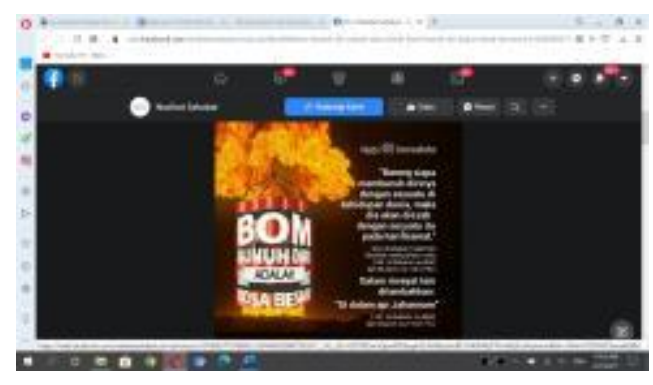

Gambar 1. contoh jihad di media online

\section{Jihad terhadap Kebodohan}

Kebodohan adalah salah satu kesalahan yang mengakibatkan seseorang sesat dalam agama. Syekh Ali Jum'ah (2016) menyatakan bahwa kelompok radikalis mengajak generasi muda untuk berpartisipasi dalam peperangan tanpa dilandasi dasar yang jelas, tanpa disertai dengan syarat-syarat, etika, serta tujuan dari jihad perang, mereka tidak tahu kapan jihad perang dilakukan, kapan dihentikan, dan ketentuan lain yang harus dimengerti. Ilmu bagi mereka merupakan hal yang tidak diutamakan.

Banyak orang yang rajin dalam beribadah, namun ibadah yang dilakukannya hanya sia-sia dan tak bermakna. Karena tanpa disadari, ia melakukan perbuatan yang dianggap benar, namun hakikatnya ia melakukan kemaksiatan. Sebagai contoh nyatadi Indonesia adalah adanya kelompok yang berpaham bahwa nasionalisme dan cinta tanah air tidak ada dasarnya. Namun mereka menganggap apa yang dilakukan merupakan sebuah ibadah.

Sebagai contoh seorang mualaf bernama FS mengunggah di dalam twitter, bahwa membela nasionalisme, nggak ada dalilnya, nggak ada panduannya. Padahal dalam membela Islam, jelas pahalanya, dan juga jelas contoh tauladannya. Sebagaimana gambar di bawah ini

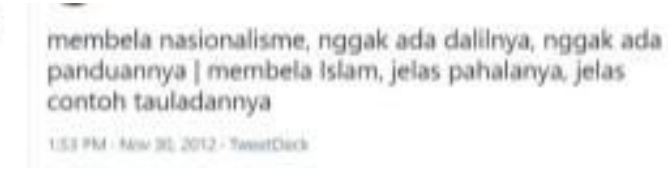

\section{Gambar 2. unggahan FS}

Jika ditelusuri literatur pendidikan di pesantren, link tersebut juga diterbitkan oleh NU Online, apa yang dilakukan FS justru merupakan sebuah kesalahan akibat dari ketidaktahuan. Khalifah kedua Sayyidina Umar, sebagaimana dinukil Syekh Ismail Haki (tt) menyatakan: 


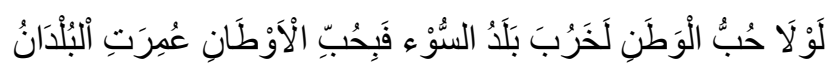

Sayyidina Umar berkata: "Seandainya tidak ada cinta tanah air, hancurlah negara yang terpuruk. Dengan cinta tanah air, negara akan Berjaya (Ibrahim, 2021).” Dari sini dapat diketahui kesalahan FS dalam menebarkan konten yang radikal.

Pernyataan FS di atas ditandingi dengan pernyataan dari tweet Nahdlatul Ulama yang mengutip pernyataan HL: Karena kami cinta Allah dan Rasulnya, kami mencintai tanah air ini. Cinta tanah air sebagai wujud terima kasih kami kepada Allah dan Rasul-Nya (Habib Lutfi, 2019). Sebagaimana gambar di bawah ini

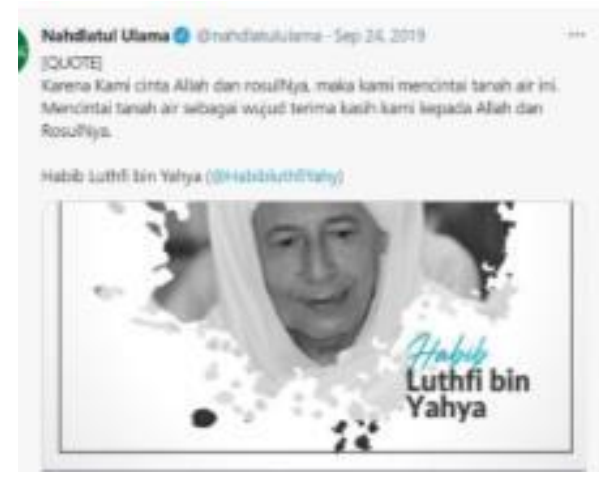

Gambar 3. tweet Nahdlatul Ulama

Dari beberapa pernyataan media online di atas, dalam perspektif pendidikan pesantren, wajib kifayah bagi setiap muslim untuk menyuarakan kebenaran dengan menampilkan argumentasi yang benar. Sebagaimana pernyataan Imam An-Nawawi: Termasuk fardlu kifayah adalah menjelaskan argumentasi keagamaan dan mengurai kejanggalan dalam memahami agama.

\section{Jihad terhadap Kebencian}

Masyarakat di era media sosial saat ini mudah sekali mengakses konten berita dan gagasan yang ada di internet. Namun di balik kemajuan teknologi tersebut, ada saja dampaknya seperti banyaknya ujaran kebencian yang dapat membuat pemikiran seseorang tidak jernih. Pemikiran seseorang terhadap individu lain tidak objektif dan tidak adil. Hal itu dikarenakan sikap bencinya terhadap sesuatu sehingga mengajaknya untuk meluapkan kemarahannya. Allah SWT melarang terhadap kebencian. Dalam surat Al-Maidah ayat 8, Allah berfirman:

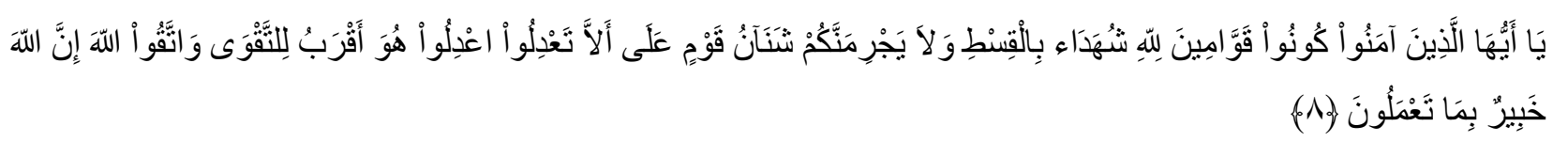

Hai orang-orang yang beriman, hendaklah kamu jadi orang-orang yang selalu menegakkan (kebenaran) karena Allah, menjadi saksi dengan adil. Dan janganlah sekali-kali kebencianmu terhadap sesuatu kaum, mendorong kamu untuk berlaku tidak adil. Berlaku adillah, karena adil itu 
lebih dekat kepada takwa. Dan bertakwalah kepada Allah, sesungguhnya Allah Maha Mengetahui apa yang kamu kerjakan.

Sebagai contoh berita pada tahun 2016, terjadi pembakaran vihara di Tanjung Balai karena adanya salah paham yang diakibatkan oleh pesan berantai (Destrianita, 2016). Pesan tersebut menjelaskan bahwa masjid dilarang memperdengarkan adzan. Tanpa ada klarifikasi terlebih dahulu, berita tersebut ditelan mentah-mentah, yang kemudian membuat marah sejumlah oknum di Tanjung Balai. Padahal jika berita tersebut diluruskan, kejadian yang memprihatinkan tersebut dapat diantisipasi dengan berita yang benar. Inilah pentingnya jihad online dalam rangka menolak terhadap berita hoaks yang membahayakan terhadap persatuan dan kedamaian di masyarakat. Berikut contoh screenshoot berita provokatif yang membuat sejumlah oknum salah paham

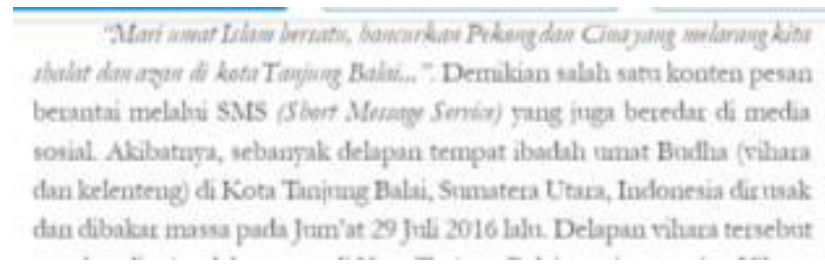

Gambar 4. berita provokatif

Berita provokatif di atas harus ditandingi dengan jihad online di media dengan konten yang menyejukkan. Jika berita provokatif tersebut tidak dilawan, maka akan cepat tersebar dan menimbulkan paham yang salah. Sebagai contoh gagasan yang menandingi adalah gagasan yang disampaikan Khalilullah (2021) di media Harakatuna sebagaimana berikut: https://harakatuna.com/jika-kamu-ngebom-rumah-ibadah-umat-beragama-lain-yang-hangussejatinya-adalah-imanmu.html.

Dalam penjelasannya, beliau mengutip penjelasan Habib Husein Ja'far Al Hadar tentang orang yang melakukan bom bunuh diri, bahwa jika kamu ngebom rumah ibadah umat beragama lain, yang hangus sejatinya adalah iтапти. Kata singkat tersebut menjelaskan bahwa orang yang melakukan bom bunuh diri tidak memiliki iman. Jika tidak memiliki iman, maka mereka bukan musli. Jika mereka bukan muslim, maka mereka kafir. Sehingga dalam hal ini yang kafir sesungguhnya adalah pelaku terorisme itu sendiri.

\section{Prognosis: Jihad Online dengan Konten yang Santun (Dakwah Bil Hikmah Wal Mauidzotil Hasanah)}

Prognosis merupakan sebuah strategi yang diambil untuk menyelesaikan persoalan dengan solusi. Berbeda dengan diagnosis yang telaahnya fokus untuk mengetahui kesalahan. Karena telaah dari prognosis adalah menyelesaikan masalah, narasi jihad online yang disuarakan adalah narasi dan konten Islam yang moderat, santun, dan toleran. 
Dalam perspektif pendidikan pesantren, nabi menjelaskan bahwa syariat Beliau adalah berdakwah untuk menyebarkan agama Allah di muka bumi ini (Al Shawi, t.t.). Namun dalam berdakwah nabi selalu mengutamakan sikap moderat dan memakai cara yang halus, hal itu sesuai firman Allah yang berbunyi:

$$
\text { ادع إلى سبيل ربك بالحكمة والمو عظة الحسنة وجادلهم بالتي هي أحسن }
$$

Serulah (manusia) kepada jalan Tuhanmu dengan hikmah dan pelajaran yang baik dan bantahlah mereka dengan cara yang baik. (Q.S. An-Nahl : 125)

Dalam ayat tersebut Allah mengajarkan tentang cara-cara berdakwah dengan kata bil-hikmah wal mau'idhotil hasanah, yaitu berdakwah dengan memakai Al-Qur'an dan membingkainya dengan kata-kata yang santun (Al Shawi, t.t). Dengan dasar tersebut, jihad dengan media online merupakan media yang efektif untuk keberhasilan dakwah, karena efektifitas dakwah tergantung terhadap relevansi media yang digunakan.

Imam At-Thobari (t.t) menjelaskan bahwa nabi berdakwah dengan lembut dan kasih sayang. Hal ini bagian dari rahmat dari Allah SWT untuk seluruh umat manusia. Sebagaimana firman Allah dalam surat Ali Imron ayat 159:



Imam At-Thobari menjelaskan bahwa dengan kasih sayang Allah SWT terhadap nabi dan umatnya, nabi berdakwah dengan kasih sayang dan memberikan kemudahan. Bahkan ketika nabi dihina dan dicaci oleh kaumnya, beliau justru mendoakan mereka dengan doa Ya Allah, berikanlah hidayah kepada kaumku, karena mereka tidak tahu. Gambar di bawah ini merupakan contoh gagasan di media online yang bersifat memberikan solusi atas segenap permasalahan

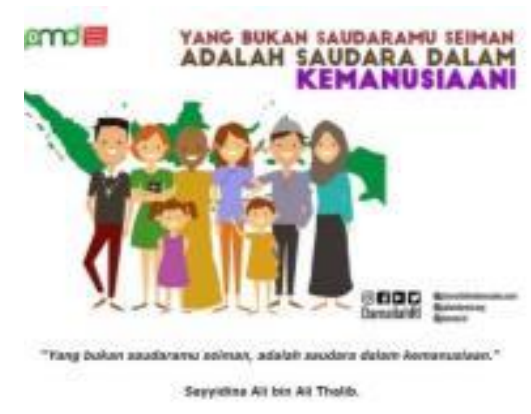

Gambar 5. Gagasan media online

\section{Motivasional: Menyuarakan Cinta Tanah Air Bagian dari Iman}

Menebarkan ajaran cinta tanah air bagian dari iman merupakan jihad online dalam bentuk pembingkaian motivasional. Jihad model ini berisi konten yang cinta tanah air, menghargai terhadap negara, membela, dan memelihara terhadap pancasila. Sebagaimana dalam literatur pendidikan 
pesantren, setiap muslim wajib membela negaranya, membela negara tidak hanya diperuntukkan bagi tantara, namun juga diperuntukkan untuk seluruh anak bangsa. Karena cinta tanah air merupakan bagian dari iman. Ketika negara berada dalam bahaya, seluruh umat Islam baik militer maupun sipil wajib mempertahankan negaranya (Himasal, 2019). Dalam kondisi damai, rakyat sipil tidak terlepas dari bela negara walaupun tidak melalui pengabdian militer. Tetapi dengan berperan aktif dan berpartisipasi sesuai dengan profesi masing-masing, guna memenuhi kebutuhan masyarakat dan negara baik dalam bidang pendidikan, ekonomi, kesehatan, teknologi, perdagangan, pertanian, dan sektor penting lainnya.

Dalam perspektif pendidikan pesantren, jihad tidak hanya dilakukan oleh militer, ketika pemerintah telah menentukan tentara yang digaji oleh negara, maka rakyat sipil harus tetap menjalankan profesi yang menunjang kemaslahatan militer, masyarakat, dan negara. Seperti pertanian, perusahaan, dan profesi lain yang dibutuhkan masyarakat. Pernyataan ini menjelaskan bahwa umat Islam dapat berjihad dengan berbagai profesi selain militer, seperti ekonomi, pertanian, kesehatan, dan lain sebagainya. Profesi yang dapat menunjang terhadap berlangsungnya kehidupan dunia hukumnya adalah fardlu kifayah yang dapat menjadi medan jihad bagi umat Islam. Bahkan menurut Imam An-Nawawi, umat Islam hukumnya fardlu kifayah untuk hidup mandiri, memenuhi kebutuhannya sendiri, memproduksi sendiri segenap kebutuhan alat, sarana, prasarana, dan teknologi (Himasal, 2019).

Dengan demikian, jihad bukanlah aksi yang mengganggu ketertiban umum dan stabilitas negara, atau usaha untuk merebut kekuasaan dan merusak kedaulatan negara. Tetap jihad merupakan pengabdian terhadap negara, melalui bela negara, dengan mempertahankan dan melindungi negara serta mensejahterakannya (Himasal, 2019).

\section{KESIMPULAN}

Jihad disesuaikan dengan situasi dan kondisi yang mengitarinya. Dengan memandang kondisi saat ini, jihad online merupakan jihad yang paling efektif untuk menumbuhkan kesadaran umat di tengah masyarakat. Jihad online dapat dilakukan dengan menggunakan media sosial seperti Facebook, YouTube, Twitter, Instagram, dan aplikasi online lainnya untuk membentengi akidah Islam ala ahlissunnah wal jamaah dan Negara Kesatuan Republik Indonesia dari serangan kelompok radikalis di media online. Jihad online dalam perspektif pendidikan pesantren dapat dimaknai sebagai perjuangan dengan menggunakan media sosial untuk menegakan kebenaran dalam menjunjung tinggi agama Islam. Jadi apapun bentuknya, perjuangan yang dilandasi dengan tujuan untuk menegakan kebenaran agama, dalam perspektif pesantren dinamakan jihad online. 
Jihad online dalam perspektif pendidikan pesantren sesuai dengan fungsi pembingkaian gagasan di media online disesuaikan dengan tiga fungsi, yaitu diagnosis, prognosis, dan motivasional. Dalam fungsi diagnosis, jihad online dalam perspektif pesantren menjadi penting dalam rangka menandingi beberapa konten yang radikal yang jelas salah. Jika konten radikal tidak ditandingi dengan konten yang moderat dan lurus, tentu stabilitas negara dan kenyamanan warga negara terganggu. Dalam fungsi prognosis, jihad online dalam perspektif pesantren menjadi strategi yang tangguh dalam rangka menyuarakan konten retorika santun (da'wah bil hikmah wal mau'idzoh hasanah). Dalam fungsi motivasional, jihad online perspektif pesantren merupakan media utama dalam menyuarakan Islam rahmatan lil 'alamiin, moderat, menyuarakan terhadap cinta tanah air bagian dari iman, serta menjaga empat pilar negara, yaitu Pancasila, Bhineka Tunggal Ika, NKRI harga mati, dan UUD 1945.

\section{DAFTAR PUSTAKA}

Abu Bakr, A.M.K. (1976). Badai’ al-Shanai’ Fi Tartib al-Syarai’.

Bahauddin, N.S. (2021). https://www.youtube.com/watch?v=IEbu0VaX_RQ.

Al-Buthi, M.S.R. (1991). Fiqh al-Sirah al-Nabawiyah.

Destrianita. (2016). Salah Paham, 7 Tempat Ibadah terbakar di Tanjung Balai. https://nasional.tempo.co/read/791846/salah-paham-7-tempat-ibadah-terbakar-di-tanjungbalai/full\&view=ok.

Sanapiah, F. \& Warseso, M.G. (1982). Metodologi Penelitian Pendidikkan.

Al-Ghazali, A.H. (1998). Ihya' Ulumuddin.

Hadi, S. (1989). Motodologi Research.

Haki, I. (t.t.). Tafsir Ruhul Bayan.

Hibban, M. (1993). Shahih Ibnu Hibban.

Huda, N. (2018). Cinta Tanah Air dalam Bingkai Ihya' Ulumuddin.

Ibrahim, R. (2019). Cinta Tanah Air Bagian dari Iman. https://islam.nu.or.id/post/read/109343/khutbah-jumat--cinta-tanah-air-bagian-dari-iman-.

Jum'ah, A. (2016). Taqdim al Kitab ar-Rad 'ala Khawarij al-Ashr. 
Khalilullah. (2021). Jika kamu ngebom rumah ibadah umat beragama lain, yang hangus sejatinya adalah imanmu. https://harakatuna.com/jika-kamu-ngebom-rumah-ibadah-umat-beragamalain-yang-hangus-sejatinya-adalah-imanmu.html.

Nadzir, M. (1996). Metode Penelitian.

Nawawi, H. (1995). Metodologi Penelitian Bidang Sosial.

Al-Nawawi, M.A.Z. (2005). Minhaj al-Thalibin.

Perdana, P.P. (2018). Dedi Mulyadi Usulkan Pemecatan PNS Anti Pancasila. https://regional.kompas.com/read/2018/11/19/15064571/dedi-mulyadi-usulkan-pemecatanpns-anti-pancasila?page=all.

Pramesti, S. (2015). Kominfo Sudah Blokir 814.594 Situs Radikal. https://nasional.sindonews.com/berita/1009534/14/kominfo-sudah-blokir-814594-situsradikal.

Ramadhan, B. (2020). Data Internet di Indonesia dan Perilakunya Tahun 2020. https://teknoia.com/data-internet-di-indonesia-dan-perilakunya-880c7bc7cd19.

Saidurrahman, T.G.S. (2019). Moderasi Beragama: Dari Indonesia untuk Dunia.

Sefriyono. (2020). Jihad Digital: Pembingkaian Narasi Kontra Radikalisasi NU Online di Dunia Maya. Jurnal Fikrah. 8.1.2020.

Al Shawi, A.M. (t.t.) Hasyiah al-Shawi.

Suryabrata, S. (1995). Metodologi Penelitian.

Thobari. (t.t.). Tafsir At-Thobari.

Lutfi, B.Y. (2019). September, 24. Quote Nahdlatul Ulama, diakses tanggal 31 Maret. https://twitter.com/nahdlatululama/status/1176274754916929537?lan.

Himasal, T.B.M. (2019). Fikih Kebangsaan III: Jihad dan Kewarganegaraan Non Muslim dalam Negara Bangsa.

Zuhaili, W. (1985). Fiqhul Islami wa Adillatihi.

Zuhaili, W. (2001). Subulul Istifadah. 